\title{
Innovations and their industrial classifications: Approach to building a new typology
}

A.V. Trachuk ${ }^{1,2}$

N.V. Linder ${ }^{1}$ ${ }^{1}$ FSBEI HE "Financial University under the Government of the Russian Federation"

2 JSC Goznak

\section{ABSTRACT}

The

he article is devoted to the analysis of research in the field of typology and classification of innovations. We consider three types of classification the second innovation: the classification by type of innovation and application; classification of innovations by degree of novelty and level of change; rating by innovation. The article proposes a fourth approach to classifying innovations as possible to manage them. The signs of controllability for classification are highlighted:

- adaptability (degree to which the innovation can be changed to satisfy requirements),

- applicability (level of use of innovation in multiple settings),

- relatedness (connected with the main business of the innovator),

- architecture (shows how much innovation should be built into the system for application (or can be used independently without rebuilding the entire system as a whole),

- autonomy (to be able to use innovation regardless of other novelties),

- centeredness (reflects the level to which innovations can influence operations that are critical to organizational effectiveness),

- sociability (the degree to which individual aspects of innovation nations can be transferred to others to form a positive attitude towards its adoption),

- compatibility (the degree to which innovation is perceived as consistent with existing values, experience and the needs of potential followers).

The types and classifications of product, technological (process), marketing, organizational and managerial innovations are examined. The so-called simulative innovations are separately considered. The analysis of the innovation activity of industrial companies made it possible to single out another new type - "value" innovations, which is the main theoretical contribution of this work.

\section{KEYWORDS:}

types of innovations, classification of innovations, product innovations; technological (process) innovations; marketing innovation; organizational innovation; managerial innovation; value innovations, simulative innovations.

\section{FOR CITATION:}

Trachuk A.V., Linder N.V. (2019). Innovations and their industrial classifications: Approach to building a new typology. Strategic Decision and Risk Management, 10(4), 296-305. DOI: 10.17747/2618-947X-2019-4-296-305 


\title{
Инновации и их классификации в прОмыШленности: пОДХОД К ПОстроению новой Типологии
}

\author{
А.В. Трачук ${ }^{1,2}$ \\ Н.В. Линдер ${ }^{1}$ \\ ${ }^{1}$ ФГОБУ ВО «Финансовый университет при Правительстве Российской Федерации» \\ ${ }^{2} \mathrm{AO} \ll$ «ознак»
}

\section{АННОТАЦИЯ}

C

татья посвящена анализу исследований в области типологии и классификации инноваций. Рассматриваются три типа классификаций инноваций: по видам или области применения; по степени новизны и уровню изменений; по признакам инноваций. В статье предложен четвертый подход к классификации инноваций - по возможности управления ими. Выделены признаки управляемости для классификации: адаптируемость (степень, до которой инновация может быть изменена, чтобы удовлетворить потребности), применимость (уровень использования инновации в различных контекстах), привязанность к основной деятельности (уровень взаимосвязи с основной деятельностью инноватора), архитектурность (показывает, насколько инновация должна быть встроена в систему для применения или может использоваться самостоятельно, без перестраивания всей системы в целом), автономность (возможность использования независимо от применения других инноваций), центрированность (отражает уровень, до которого инновации способны повлиять на операции, критически важные по отношению к организационной эффективности), коммуникабельность (степень, до которой отдельные аспекты инновации могут быть переданы другим пользователям с целью формирования положительного отношения к ее принятию), совместимость (степень, до которой инновация воспринимается как не противоречащая существующим ценностям, опыту прошлого и потребностям потенциальных последователей).

Рассматриваются виды и классификации продуктовых, технологических (процессных), маркетинговых, организационных и управленческих инноваций. Отдельно рассмотрены так называемые имитационные инновации. Проведенный анализ инновационной деятельности промышленных компаний позволил выделить еще один новый тип - ценностные инновации, что составляет основной теоретический вклад данной работы.

\section{КАЮЧЕВЫЕ САОВА:}

типы инноваций, классификация инноваций, продуктовые инновации, технологические (процессные) инновации, маркетинговые инновации, организационные инновации, управленческие инновации, ценностные инновации, имитационные инновации.

\section{АМЯ ЦИТИРОВАНИЯ:}

Трачук А.В., Линдер Н.В. (2019). Инновации и их классификации в промышленности: подход к построению новой типологии // Стратегические решения и риск-менеджмент. Т. 10. № 4. С. 296-305. DOI: 10.17747/2618-947X-2019-4-296-305 


\section{INTRODUCTION}

The first papers on the classification of innovations appeared in the late 1930s of the last century [Schumpeter, 1934; Cooper, Kleinschmidt, 1987b; Robb, 1989; Henderson, Clark, 1990; Burningham, West, 1995; Neely, Hii, 1998]. The authors agreed that the typology of innovation has a significant impact on various aspects of research. Thus, Rogers (1962) showed that the type of innovation has a substantial effect on the adoption and dissemination of innovation. In [Cooper, Kleinschmidt, 1987a; 1993; Danneels, Kleinschmidt, 2001] show the impact of types of innovation on company productivity, and in [Pelz, 1983; King, 1992; Fernández, 2001] states that the type of innovation influences the construction of the innovation process in a company.

It should be noted that all existing classifications can be divided into three types according to classification approaches:

- the first approach: classifying innovations by type or field of application;

- second approach: classification of innovations according to the degree of novelty and level of changes;

- the third approach: classification by signs of innovation.

\section{CLASSIFICATIONS OF INNOVATIONS BY TYPE AND SCOPE}

The classic typology of innovation is the classification proposed by the OECD. According to this typology, five types of innovations are distinguished [OECD Handbook, 2005]:

- product innovations;

- technological (process) innovations;

- marketing innovations;

- organizational innovation;

- management innovations.

Product innovation. The OECD defines this type of innovation as the launch of goods or services that have fundamentally new or significantly improved properties. Significant improvements in product properties are associated with technical specifications, materials used, customer value or other functional features.

Utterback and Abernathy [Utterback, Abernathy, 1978] define product innovation as new technology or a combination of new technologies that have gained commercial distribution in the market.

Rainey in his works [Rainey, 2005. P. 1-2] added that the primary goal of product innovation is to improve the company's strategic position in the market with the help of creativity and leadership. He also suggested that the strategic sustainability of the company depends on the introduction of product innovations to the market, as it reduces the pressure of competitors and the business environment.

Rainey [Rainey, 2005. P. 2] recognized as product innovation:

- study of the needs for new products, processes and services;

- determination of the direction of development and markets for new products;

- formation of a development strategy and commercialization of new products;
- the choice of opportunities for investment in a new product;

- the organizational structure improvement to create commercially successful new products;

- the process of new product creation and the R\&D program implementation by the company.

Moore [Moore, 2005. P. 65] defined product innovation as an innovation focused on existing markets and existing products, adding features or functions to goods that are not on the market in the current period. He noted that the success of this type of innovation depends on how quickly the innovation is brought to market compared to competitors. The sooner the product is launched on the market, the higher the chance of success.

Ulwick [Ulwick, 2005. P. 2] in his work writes that for companies to succeed in the market, they need to continually search for those consumer needs that are poorly served in the market, and following this, it is necessary to refine their products or offer something new. At the same time, he believes that the more unmet needs a company can satisfy, the more success it will achieve. So, the success of a new product is more likely if this product serves not just one need, but several.

Technological (process) innovations. OECD [OECD, 2005. P. 49] defines this type of innovation as "introducing a new or significantly improved production method or delivery method." The OECD Oslo Manual includes in this type of innovation:

- significant changes in methods, equipment and / or software;

- new or significantly improved methods for creating and providing services;

- substantial changes in the hardware and / or software of service companies providing services;

- significant changes in the procedures or methods that are used to provide services;

- new or significantly improved methods, equipment and software in auxiliary operations;

- the introduction of new or significantly enhanced information and communications;

- technologies (ICTs) designed to increase the effectiveness and / or quality of supporting activities.

According to Davenport [Davenport, 1992. P. 1], process innovation is the introduction of innovation into the company's key business processes. Moreover, a business process can be defined as "a complete, dynamically coordinated set of activities or logically related tasks that must be completed to create value for clients or fulfil other strategic goals" [Trkman, 2010].

Process innovation has an internal focus and seeks to increase the efficiency of internal organizational processes to simplify the production and delivery of goods or services to customers [Utterback, Abernathy, 1978].

Moore [Moore, 2005. P. 69], indicates that due to process innovations, firms increase profit margins, benefiting not from the product itself, but the production processes of the products. The goal of process innovation is to remove non-steps in the value chain that do not add value to customers.

Technological (process) innovations occur when new elements are introduced into the production system or service work to produce its products or provide services to customers [Utterback, Abernathy, 1978]. Technological innovation is changing the operational processes and systems of an organization [Hage, Meeus, 2006. P. 23]. 
Process innovations are used to reduce the cost of a unit of production or its supply, improve quality. In addition, there may be a correlation between process and product innovations, since radical innovations typically involve not only changes in the product or service itself, but also, probably, the process of its manufacture and delivery [Reichstein, Salter, 2006].

Marketing innovation. OECD [OECD, 2005. P. 48] gives the most recognized definition of marketing innovation. In the OECD Guidelines for Oslo, marketing innovation is defined as "introducing a new marketing method that involves significant changes in product development or packaging, product placement, product promotion, or pricing." New marketing methods can be implemented for both new and existing products. Their goal (together to increase the sales of the company):

- better customer satisfaction,

- opening up new markets,

- new product launch on the market.

One of the earliest references to marketing innovation belongs to Levitt [Levitt, 1962. P. 102]. He tried to analyze the dependence of "profit growth on planned marketing innovation." According to Levitt, marketing innovation is a random process and is entirely dependent on the products and markets that a new product or service is moving into. He argued that the invention of new marketing methods should accompany every product innovation.

Marketing innovations were further developed in the writings of Moore (Moore 2005. P. 88-90], who believed that marketing innovations should be focused on interactive communication with potential consumers, enrich their consumer knowledge, and facilitate marketing communications.

Chen [Chen, 2006] first identified two types of marketing innovations: innovations that allow firms to get to know their customers better in order to increase the consumer value of goods and innovations that reduce consumer operating costs.

A distinctive feature of marketing innovation in comparison with simple changes in the marketing tools used by the company is the introduction of a new comprehensive marketing method previously not used by the company. This means that there must be a new marketing concept that represents a significant departure from the existing marketing methods of the firm [Organization for Economic Cooperation..., 2005. P. 48-51].

Organizational innovation. OECD [OECD, 2005. P. 51] defines organizational innovation as "the introduction of a new organizational method in a firm's business practice, workplace organization or external relations." The purpose of organizational innovation is:

- to improve the performance of the company by reducing administrative or operating costs,
- to increase productivity jobs,

- to reduce delivery costs.

Distinctive features of organizational innovation compared with other organizational changes in the organization is "the introduction of an organizational method that has not been used before in the organization and is the result of strategic decisions made by the management" [OECD, 2005. P. 48-51].

Organizational innovation shows the creation or adoption of a new idea or behaviour in an organization. Also, this type of innovation is Damanpour and Evan [Damanpour, Evan, 1984] is considered a response to organizations' commitment to environmental compliance. "Organizations can cope with environmental change and uncertainty by successfully integrating technical or administrative changes in their organizational structure that improve the level of achievement of their goals" [Damanpour, Evan, 1984].

In the work of Gurkov and Tubalov [Gurkov, Tubalov, 2004] organizational innovations are divided into two types: intra-company and inter-company. The authors understand intra-company innovation as "the creation of new forms of differentiation, integration and control of work within departments or between departments, but within a firm," whereas the inter-company innovations are innovations that "change the relationship between firms, as within value chains (relations between suppliers, consumers and contractors), as well as within groups of firms connected by relations of common ownership and control."

Managerial innovation. The study of managerial innovation relates to the period between 1960-1980; however, for a long time, marketing and organizational innovations were considered as part of managerial innovations. Managerial innovations were defined more accurately in Daft's work [Daft, 1978. P. 195], who divided process innovation into two categories: technological and managerial. Managerial innovations are new approaches and methods for motivating and rewarding employees, changing organization management processes, approaches to strategy formation, planning, etc. [Daft, 1978]. They affect changes in the structure and administrative processes of the organization, knowledge management systems, etc., and allow the formation of managerial skills for the successful functioning of the organization [Damanpour et al., 2009. P. 654-655]. They also reflect approaches to developing a strategy, structure, and new business processes for an organization [Kimberly, 1981; Walker et al., 2011; Vaccaro et al., 2012].

In the work of Gurkov and Tubalov [Gurkov, Tubalov, 2004] managerial innovations are divided according to the nature of their impact into three classes: adding innovations, replacing innovations and eliminating innovations. Moreover, by adding

Table 1

Approach to the classification of innovations of Bessant and Tidd

Types of Innovation

Production innovation

Process innovation

Position innovation

Paradigm innovation
Their description

Production of new products or services, as well as improved products or services with additional features The introduction of a new technology, method or tool for the production of a product or service A change in the positioning of a particular product or service or a change in a business segment Changing the principles of the company, its strategy, business model, etc.

Source: compiled by the author based on [Bessant, Tidd, 2007]. 
Table 2

Approach to the classification of innovations Gurkov, Tubalov

Innovation classes

Product

Technical

Managerial technologies

Organizational intra-

company

Organizational inter-

company

\section{Their description}

Change in what is being done or offered to consumers

Includes products, processes, and technologies used to produce goods or provide services.

Changes in the forms of work in the field of finance, marketing, personnel management, etc.

New forms of differentiation, integration and control of work within departments or between departments, but within the company

New forms of differentiation, integration and control of work between firms, or within groups of firms associated with relations of common ownership and control

Compiled by the author based on: [Gurkov, Tubalov, 2004].

Table 3

Approach to the classification of innovations Gurkov, Tubalov by the degree of connectivity of innovations

\section{Types of innovation by degree of connectivity}

Parallel (independent) innovations

Sequential innovation

Synergetic (mutually reinforcing) innovations

\section{Description of Innovation}

each innovation is designed to solve a clearly defined problem, not being an integral part of the system of new forms of activity;

events that are a logical continuation of the work already done, but, despite the name, such innovations can be implemented at the same time;

a complex of innovative measures that allows to achieve the effect of the joint implementation of more than the implementation of any one measure.

Compiled by the author based on: [Gurkov, Tubalov, 2004].

innovations, authors understand innovations, the result of which is the expansion of existing practices; under replacement innovations - new practices that serve as a replacement for one or more existing practices; under eliminating - "refusal (withdrawal) of an individual function or several functions from management practice" [Gurkov, Tubalov, 2004].

Another example of the classification of innovation is the identification of four types of innovation in the work of Bessant and Tidd [Bessant, Tidd, 2007] (table 1). This classification has much in common with the OECD classification. For instance, the production type of innovation is an analogy of product innovation; position innovation can be seen as a marketing innovation in the OECD concept. However, Bessant and Tidd introduce the concept of an innovation paradigm, which is much broader than organizational and managerial innovations in the OECD methodology and covers all changes in the company's behaviour and its strategy.

Also a classification that is close in significance to the Oslo Manual's classification is presented in the work of Gurkov, Tubalov [Gurkov, Tubalov, 2004], in which the authors identify five classes of innovation in the activities of the company: product, technical, managerial technologies, organizational intracompany and organizational inter-company innovations (table 2).

In addition to this classification, the authors present a classification according to the degree of connectivity of innovations into parallel (or independent) innovations, sequential innovations and synergetic (mutually reinforcing) innovations (table 3), which seems to us a new approach to the classification of innovations.

\section{CLASSIFICATION OF INNOVATIONS BY NOVELTY DEGREE AND CHANGE LEVEL}

Another approach to the classification of innovations is to establish the degree of "strength" or "intensity" of change. Thus, the degree of innovation ranges from "incremental innovation" to "technological revolution" [Freeman et al., 1982], from the "ordinary" to the "revolutionary" type of change. Coccia [Coccia, 2006] in his work identifies seven levels of intensity of innovative changes (from the "easiest" to "revolutionary") and gives examples of classifications of innovations according to the degree of their innovative intensity. Garcia and Calantone [Garcia, Calantone, 2002] also conduct a comprehensive review of the types of innovations and classify innovations according to the type of intensity of change.

Garcia and Calantone [Garcia, Calantone, 2002. P. 102] point out that radical innovations embody new technology that leads to new market infrastructure. Consequently, radical innovation represents something new to the world and does not follow existing technology. Research also confirms that these types of innovations usually provide significant technological breakthroughs and create new knowledge [Ahuja, Lampert, 2001].

Radical innovations represent more revolutionary changes in underlying technologies and control systems [Rainey, 2005. P. 45]. Accordingly, researchers emphasize that, due to the 
Table 4

Comparative characteristics of radical, incremental and disruptive innovations

\begin{tabular}{|c|c|c|}
\hline Radical innovation & Incremental innovation & Disruptive innovation \\
\hline Using new technologies & Using existing technology & Using both new technologies and existing ones \\
\hline Existing or New Market & Existing market & Creating a new market \\
\hline $\begin{array}{l}\text { Focus on processes and products } \\
\text { with unique features }\end{array}$ & $\begin{array}{l}\text { Focus on reducing costs or improving existing } \\
\text { products, processes, marketing methods or } \\
\text { organizational structures. }\end{array}$ & $\begin{array}{l}\text { Does not satisfy the needs of the next generation of } \\
\text { consumers, but creates new needs }\end{array}$ \\
\hline
\end{tabular}

Source: compiled by the authors.

difficulties and risks involved in the development, radical innovations are very rare [Hitt et al., 2007. P. 414].

Garcia and Calantone [Garcia, Calantone, 2002. P. 121] show that radical innovation leads to the creation of new industries with new competitors, firms, distribution channels, and new marketing innovations.

Hitt, Ireland and Hoskisson [Hitt et al., 2007. P. 413] believe that radical innovations provide consumers with new functions and features, so successful radical innovations are more likely to increase revenue and profits for the company.

OECD [OECD, 2005. P. 58] defines radical innovation as an innovation that has "a significant impact on the market and on the economic activity of firms in that market."

Incremental innovation implies ongoing product improvements according to customer requirements. This type of innovation takes two forms [OECD, 2005. P. 80]:

- improvement of a simple product (in terms of improved performance or lower price) through the use of components of a higher level, performance or materials,

- improvement of a complex product consisting of many integrated technical subsystems by improving one or more of the subsystems.

Garcia and Calantone [Garcia, Calantone, 2002. P. 123] define incremental innovation as products that offer new features, benefits, or improvements to existing technology in a given market. At the same time, markets for incremental innovations are already known; product features are well understood; profit margins are lower; production technologies are effective; and competition is primarily based on price [Hitt et al., 2007. P. 413].

Most innovations are incremental because they are based on existing products and provide only minor improvements. Incremental innovation may include adapting, processing, or improving existing products [Garcia, Calantone, 2002. P. 123].

According to Yen and Wei [Yen, Wei, 2009. P. 297-298], incremental innovation helps companies maintain profit share and market share, while radical innovation can have three directions of change:

- expanding the boundaries of the existing market or creating a new potential market,

- the formation of the image of the company as an innovator, which affects the increase in brand value,

- increase in company income.

In the work of Christensen and Overdorf [Christensen, Overdorf, 2000. P. 72] disruptive innovations are defined as innovations that "create an entirely new market by introducing a new type of product or service". It may be a product or service that is significantly worse than the product initially used by consumers. So, Christensen [Christensen, 1997] indicates that disruptive innovations do not meet the needs of the next generation of customers in existing markets; they allow new needs and markets to emerge. Disruptive technology products are usually cheaper, simpler, and often more convenient to use.

Christensen and Overdorf [Christensen, Overdorf, 2000. P. 73] point out that incremental innovations are typically designed and presented by well-known industry leaders, while disruptive innovations may be born in new companies.

A comparative analysis of radical, incremental and disruptive innovations is given in table 4 .

\section{INNOVATION CLASSIFICATIONS}

Another classification of innovation is the so-called multilayer classification - when two areas of novelty are distinguished: technological and market changes, and three degrees of this novelty in each direction. The first such classification was given by Johnson and Jones (1957) [56]. Subsequently, similar types of innovation classifications have been used by many authors (e.g., [Moore, 2005]). An example of a multilayer classification is presented in table 5 .

More recent examples of multilayer classification are presented, for example, in the work [Zawislak et al., 2011], in which innovations are divided into two types: innovations due to technological changes and innovations due to market changes (table 6).

Another type of classification can be called the classification of innovation along the life cycle, developed by Moore [Moore, 2005]. He identified 14 types of innovation according to the life cycle (table 7).

Thus, the analysis of various types of innovations and approaches to their classification allows us to distinguish the following types of innovations:

1) classic types of innovations: process, product, managerial, organizational, marketing;

2) innovations classified by the degree of novelty: radical, breakthrough - can be classified as "strong innovative changes", while incremental ones are considered as "weak innovative changes"; 
Table 5

Example of a multi-layered classification of innovation

\begin{tabular}{|c|c|c|}
\hline $\begin{array}{l}\text { Types of } \\
\text { Innovation }\end{array}$ & Novelty level & Goal \\
\hline \multicolumn{3}{|c|}{ Unchanged market } \\
\hline Reformatting & $\begin{array}{l}\text { Advanced } \\
\text { technology }\end{array}$ & $\begin{array}{l}\text { The optimal ratio } \\
\text { of cost, quality and } \\
\text { availability of new } \\
\text { products }\end{array}$ \\
\hline Replacement & New technology & $\begin{array}{l}\text { Search for new } \\
\text { components, materials } \\
\text { or technologies not used } \\
\text { by the company }\end{array}$ \\
\hline \multicolumn{3}{|c|}{ Improved market } \\
\hline Reformatting & No change & $\begin{array}{l}\text { Increase sales to new } \\
\text { types of consumers }\end{array}$ \\
\hline Superior product & $\begin{array}{l}\text { Advanced } \\
\text { technology }\end{array}$ & $\begin{array}{l}\text { Products with Better } \\
\text { Properties and Greater } \\
\text { Consumer Benefits }\end{array}$ \\
\hline $\begin{array}{l}\text { Product Line } \\
\text { Expansion }\end{array}$ & New technology & $\begin{array}{l}\text { Expanding product line } \\
\text { to reach new customers }\end{array}$ \\
\hline \multicolumn{3}{|c|}{ New market } \\
\hline New use & No change & $\begin{array}{l}\text { Finding new types of } \\
\text { consumers who can use } \\
\text { the company's products }\end{array}$ \\
\hline Market expansion & $\begin{array}{l}\text { Advanced } \\
\text { technology }\end{array}$ & $\begin{array}{l}\text { The formation of new } \\
\text { classes of consumers } \\
\text { by changing existing } \\
\text { products }\end{array}$ \\
\hline Diversification & New technology & $\begin{array}{l}\text { New consumers using } \\
\text { new technologies }\end{array}$ \\
\hline
\end{tabular}

Compiled by the authors based on [Jones, Johnson, 1957].

Table 6

An example of a multilayer classification of innovations according

\begin{tabular}{|c|c|}
\hline $\begin{array}{c}\text { Types of } \\
\text { Innovation }\end{array}$ & Description \\
\hline \multicolumn{2}{|r|}{ Technology Change Innovation } \\
\hline $\begin{array}{l}\text { Technological } \\
\text { innovation }\end{array}$ & $\begin{array}{l}\text { Development of a new design, new } \\
\text { materials and new products, as well as the } \\
\text { development of new equipment and new } \\
\text { components. }\end{array}$ \\
\hline $\begin{array}{l}\text { Operational } \\
\text { innovation }\end{array}$ & $\begin{array}{l}\text { New processes, improvements to existing } \\
\text { processes, the introduction of modern } \\
\text { methods, new locations in order to produce } \\
\text { products with quality, efficiency, flexibility } \\
\text { at the lowest cost. }\end{array}$ \\
\hline \multicolumn{2}{|r|}{ Market driven innovation } \\
\hline $\begin{array}{l}\text { Management } \\
\text { innovation }\end{array}$ & $\begin{array}{l}\text { Development of management skills to } \\
\text { create new management methods and a new } \\
\text { business strategy, improve decision making } \\
\text { and cross-functional coordination, etc. }\end{array}$ \\
\hline $\begin{array}{l}\text { Transactional } \\
\text { Innovation }\end{array}$ & $\begin{array}{l}\text { New ways to minimize transaction costs for } \\
\text { relationships with suppliers and customers. } \\
\text { Creation of new commercial strategies, etc. }\end{array}$ \\
\hline
\end{tabular}

Compiled by the authors based on [Zawislak et al., 2011].
Table 7

Classification of Innovation "Along the Life Cycle" of Innovation

\section{Types of Innovation \\ Description of Innovation}

\section{Product Leadership Zone}

Disruptive Innovation

Creation of new market categories based on disruptive technology or disruptive business model

Applied Innovation

Development of new markets for existing products, search for opportunities for their new use.

Innovation for existing markets and for existing products. The goal is to improve existing

Product Innovation products and develop new product features and functions that are not currently on the market.

Platform innovation

Focus on improving value for future generations of consumers

\section{Customer proximity}

Structural modifications to the

Additional linear innovation

existing proposal to create distinctive subcategory.

Improved innovation

Continuation of the path to improve the existing product.

Marketing innovation

New methods of interaction with a potential client during the procurement process.

Experience Based Innovation

Creating a new value is not based on differentiating functionality, but rather on differentiating the supply experience.

\section{Operational Improvement Zone}

Innovation in increment of technical value

The increment of value through the use of new materials and technologies, without changing its external properties of the product.

Reduce customer service costs

Innovation in integration by integrating disparate elements into a single system with centralized management.

Focusing on increasing profits

Process innovation by improving the processes of production and service of the product.

\section{Product Category Renewal Area}

Innovations in Value

Migration

Fundamental transformation of the company's business model

Organic innovation Using domestic resources to change their market position and further growth

Improving products, services,

Acquisition innovation business models through mergers and acquisitions

Compiled by the authors based on [Moore, 2005]. 
3) innovations having a multilayer classification: according to the type of market and types of innovative changes in each of them; by types of drivers of innovative changes, etc.;

4) innovations classified by the life cycle of the course of the innovation process.

At the same time, in numerous modern works devoted to innovations, there are many new types of innovations that are not described by existing classifications. So, in our opinion, it is necessary to highlight another type of innovation - value innovation. This type of innovation is not associated with a change in some innovation (product, technological, etc.), but is aimed at transforming the value created and transmitted by the company to the consumer. Examples of this type of innovation are lean innovation, organic innovation, and business model innovation.

All concepts of innovations are related to management and, in this regard, in our opinion, it is necessary to develop a new classification of types of innovations by the sign of their use to describe innovation management processes. Such a classification will be necessary for both researchers and practitioners, as it will allow a more accurate understanding of the types of innovations, their impact on the real increase in the value of products and services for customers, as well as on the ability of companies to achieve strategic goals.

\section{APPROACHES TO CLASSIFYING INNOVATIONS FROM THE POINT OF VIEW OF THEIR MANAGEMENT}

To create such a classification, we first of all identified all the characteristics used to manage them (table 8). In our opinion, there are 8 key characteristics by which innovations can be divided from the point of view of managing them.

\section{CONCLUSION}

Thus, in scientific literature there is a wide range of definitions, types and classification concepts. Therefore, there is no general understanding of the term an innovation, his forms and, at last, influences, and the term the innovation is used according to use purpose.

The analysis of various types of innovations and approaches to their classification allows to allocate the following types of innovations:

1) classical types of innovations: process, grocery, administrative, organizational, marketing;

2) the innovations classified by degree of novelty: radical, breakthrough - can be classified as "strong innovative changes" while the incremental are considered as "weak innovative changes";

3) the innovations having multilayered classification: as the market and to types of innovative changes on each of them; on types of drivers of innovative changes, etc.;

4) the innovations classified by life cycle of course of innovative process.

At the same time, in the numerous modern works devoted to innovations the set of new types of the innovations which haven't been described by existing classifications meets. So, our look, allocation of one more type of innovations - valuable innovations is necessary. This type of innovations is connected not about change of any type of innovations (grocery, technological, etc.), and directed on transformation of the value created and broadcast by the company to the consumer. Examples of innovations of this kind are economical innovations, organic innovations, innovations business - models etc.

All concepts of innovations are connected with management and, in this regard, we have offered new classification of types of innovations on the basis of their use for the description of management of innovations. We have allocated controllability signs for classification: adaptability (level of use of an innovation

Table 8. Classification of innovations from the position of their management

\begin{tabular}{|c|c|}
\hline Characteristic & Description \\
\hline Adaptability & The extent to which innovation can be modified to meet needs. \\
\hline Applicability & Level of innovation used in various contexts \\
\hline Architecture & $\begin{array}{l}\text { It shows how much innovation should be built into the system for application (or can be used independently without } \\
\text { rebuilding the entire system as a whole) }\end{array}$ \\
\hline Centeredness & $\begin{array}{l}\text { "Centering" - "peripherality": reflects the level to which innovations can affect operations that are critical to } \\
\text { organizational performance. }\end{array}$ \\
\hline Sociability & $\begin{array}{l}\text { The degree to which certain aspects of innovation can be passed on to others in order to create a positive attitude } \\
\text { towards its acceptance. }\end{array}$ \\
\hline
\end{tabular}


in various contexts), applicability (level of use of an innovation in various contexts), attachment to primary activity (coherence with primary activity of the innovator), an arkhitekturnost (shows as far as the innovation has to be built in system for application (or it can be used independently without perestraivaniye of all system as a whole), autonomy (possibility of application of an innovation irrespective of application of other innovations), centrality (reflects level to which innovations are capable to influence the operations crucial in relation to organizational efficiency), skill to communicate (degree to which separate aspects of an innovation can be transferred to another, for the purpose of formation of the positive relation to her acceptance), compatibility (degree to which the innovation is apprehended as consistent with existing values, experience of the past and needs of potential followers). Such classification is necessary as for researchers, and practicians as will allow to understand more precisely types of innovations, their influence on real increase of value of products and services for clients, and also on possibility of the companies of achievement of strategic objectives.

\section{REFERENCES}

1. Ahuja G., Lampert M. (2001). Entrepreneurship in the large corporation: A longitudinal study of how established firms create breakthrough inventions. Strategic Management Journal, 22, 521-543.

2. Chen Y. (2006). Marketing Innovation. Journal of Economics \& Management Strategy, 15, 101-123.

3. Christensen M.Cs. (1997). The innovator's dilemma: When new technologies cause great firms to fail. Boston, Harvard Business School Press.

4. Christensen M.C., Overdorf M. (2000). Meeting the challenge of disruptive change. Harvard Business Review, 78, 66-77.

5. Coccia M. (2006). Classifications of innovations survey and future directions. Working Paper CERIS-CNR, Anno 8, 2, 2006.

6. Damanpour F., Evan W.M. (1984). Organizational innovation and performance: the problem of "organizational lag". Administrative Science Quarterly, 29 (3), 392-409.

7. Damanpour F., Walker R.M., Acellaneda C.N. (2009). Combinative effects of innovation types and organizational performance: a longitudinal study of service organizations. Journal of Management Studies, 46 (4), 650-675.

8. Daft R. L. (1978). A dual-core model of organizational innovation. Academy of Management Journal, 21, 193-210.

9. Davenport H.T. (1992). Process innovation: reengineering work through information technology. Boston, Harvard Business Press.

10. Freeman C. (1982). The Economics of Industrial Innovation. The MIT Press.
11. Garcia R., Calantone R. (2002). A Critical look at technological innovation typology and innovative terminology: a literature review. Journal of Product Innovation Management, 19 (2), 110-132.

12. Gurkov I. B., Tubalov V.S. (2004). Innovations in Russian industry: creation, diffusion and implementation of new technologies and social practices. World of Russia, 3.

13. Hage J., Meeus M. (2006). Innovation, science, and institutional change. Oxford, Oxford University Press.

14. Hitt M.A., Ireland D. R., Hoskisson E.H. (2007). Strategic management: competitiveness and globalization (concepts and cases). Mason, Thomson South-Western.

15. Johnson S.C., Jones C. (1957). How to organize for new products. Harvard Business Review, 5-6, 49-62.

16. Kimberly J.R. (1986). The organization context of technological innovation. In: Davis D. D. (ed.). Managing technological innovation. San Francisco, Jossey-Bass.

17. Levitt T. (1962). Innovation in marketing: new perspectives for profit and growth. New York, McGraw-Hill Professional.

18. Moore G.A. (2005). Dealing with Darwin: How great companies innovate at every phase of their evolution. New York, Portfolio.

19. OECD (2005). Oslo Manuals. Guidelines for Collecting and Interpreting Innovation Data. 3rd ed. Paris, OECD.

20. Rainey D.L. (2005). Product innovation: leading change through integrated product development. New York, Cambridge University Press.

21. Reichstein T., Salter A. (2006). Investigating the sources of process innovation among UK manufacturing firms. Industrial and Corporate Change, 15 (4), 653-682. DOI: 10.1093 / icc / dt1014.

22. Trkman P. (2010). The critical success factors of business process management. International Journal of Information Management, 30 (2), 125-134.

23. Utterback J., Abernathy W. (1978). Patterns of industrial innovation. Technology Review, 80, 41-47.

24. Ulwick A. (2005). What customers want: using outcome-driven innovation to create breakthrough products and services. New York, McGraw-Hill Professional.

25. Vaccaro I. G., Jansen J. J.P., Van Den Bosch F.A. J., Volberda H. (2012). Management innovation and leadership: The moderating role of organizational size. Journal of Management Studies, 49 (1), 28-51.

26. Walker R. M., Damanpour F., Devece C.A. (2011). Management innovation and organizational performance: Mediating role of planning and control. Journal of Public Administration Research and Theory, 21, 367-386.

27. Zawislak P.A. et al. (2011). Innovation capabilities of the firm: The brazilian experience. 9th Globelics International Conference (GLOBELICS). 


\section{ABOUT THE AUTHORS}

\section{Arkady V. Trachuk}

Dr. in Economics, Professor, head of the Management Department, Scientific Superviser of the Management Faculty of the Financial University under the Government of the Russian Federation, General Director of Goznak JSC.

Research interests: strategy and management of the company's development, innovation, entrepreneurship and modern business models in the financial and real sectors of the economy, dynamics and development of e-business, operating experience and prospects for the development of natural monopolies.

E-mail: ATrachuk@fa.ru

\section{Natalia V. Linder}

Cand. of Scien. in Economics, Professor, first deputy head of the Management Department of the Financial University under the Government of the Russian Federation.

Research interests: strategy and development management companies, formation of development strategy of industrial companies in the context of the fourth industrial revolution, innovation transformation of business models, dynamics and development of e-business development strategies of companies in the energy sector in the fourth industrial revolution, exit strategies of Russian companies on international markets.

E-mail: NVLinder@fa.ru

\section{ИНФОРМАЦИЯ ОБ АВТОРАХ}

\section{Аркадий Владимирович Трачук}

Доктор экономических наук, профессор, руководитель Департамента менеджмента, научный руководитель факультета менеджмента ФГОБУ ВО «Финансовый университет при Правительстве Российской Федерации», генеральный директор АО «Гознак».

Область научных интересов: стратегия и управление развитием компании, инновации, предпринимательство и современные бизнес-модели в финансовом и реальном секторах экономики, динамика и развитие электронного бизнеса, опыт функционирования и перспективы развития естественных монополий.

E-mail: Trachuk_A_V@goznak.ru

\section{Наталия Вячеславовна Линдер}

Кандидат экономических наук, профессор, первый заместитель руководителя Департамента менеджмента ФГОБУ ВО «Финансовый университет при Правительстве Российской Федерации».

Область научных интересов: стратегия и управление развитием компаний, формирование стратегии развития промышленных компаний в условиях четвертой промышленной революции, инновации и трансформация бизнес-моделей, динамика и развитие электронного бизнеса, стратегии развития компаний энергетического сектора в условиях четвертой промышленной революции, стратегии выхода российских компаний на международные рынки.

E-mail: NVLinder@fa.ru 